\title{
Museu: da fruição estética ao entretenimento
}

\author{
Bernardete Oliveira Marantes ${ }^{1}$
}

Resumo: O ensaio de Walter Benjamin, A obra de arte na era de sua reprodutibilidade técnica ${ }^{2}$ é ainda um farol no tocante à reflexão sobre a feitura e a recepção da obra de arte. A proposta deste ensaio é adentrar, munidos do pensamento benjaminiano, os museus e pensar sobre as alterações ocorridas tanto na fruição da arte pelo visitante, quanto no caráter comercial assumido por estes espaços.

Palavras-chave: Benjamin, arte, museu, recepção estética, consumismo.

Abstract: The essay of Walter Benjamin The Work of Art in the Age of Mechanical Reproduction, is still a beacon with respect to reflection on the making and reception of the artwork. The purpose of our essay is to enter, in possession of Benjamin's thought, the museums and think about the changes in the enjoyment of art by the visitor, and also reflect about the commercial character assumed by these spaces.

Keywords: Benjamin, art, museum, aesthetic reception, consumerism.

I

Conforme Walter Benjamin, o que fundamenta a autenticidade ${ }^{3}$ de um objeto artístico é sua unicidade que "é idêntica à sua inserção no contexto da tradição"4, ou seja, só o objeto autêntico é único e capaz de fundar uma história, de iniciar uma tradição. Com a introdução e a aceleração das novas técnicas de reprodução das imagens, primeiro a fotografia e depois o cinema, houve uma interrupção na tradição estética e esta ruptura provocou uma perda irremediável ao objeto artístico: "à mais perfeita reprodução mecânica falta sempre algo: o aqui e agora da obra de arte" ${ }^{, 5}$ então, na era da reprodutibilidade técnica inexiste o conteúdo mesmo, a essência, "a unicidade da obra ou, em outras palavras, sua aura"6.

O conceito benjaminiano de aura $^{7}$, de modo genérico, alude ao atávico, ao mágico, ao teleológico, como se a ideia de aura vaticinasse um sentido metafísico e religioso intrínseco na obra, por isso, "esse

\footnotetext{
${ }^{1}$ Doutoranda em Filosofia da Universidade de São Paulo, sob a orientação do Prof. Dr. Franklin Leopoldo e Silva.

${ }^{2}$ Texto-base do artigo: BENJAMIN, Walter. A obra de arte na era de sua reprodutibilidade técnica (p. 165-196) (Primeira versão). In: Magia e técnica, arte e política: ensaios sobre literatura e história da cultura. São Paulo: Brasiliense, 1994.

3 "O aqui e agora do original constitui o conteúdo da sua autenticidade, e nela se enraíza uma tradição que identifica esse objeto, até nossos dias, como sendo aquele objeto, sempre igual e idêntico a si mesmo. A esfera da autenticidade, como um todo, escapa à reprodutibilidade técnica, e naturalmente não apenas a técnica". In: BENJAMIN, 1994, p. 167.

${ }^{4}$ BENJAMIN, 1994, p. 170.

${ }^{5}$ BENJAMIN, 1993, p. 7.

${ }^{6}$ BENJAMIN, 1994, p. 171.

${ }^{7}$ Tratamos aqui o conceito de aura sempre no sentido de uma teoria da arte.
} 
modo de ser aurático da obra de arte nunca se destaca completamente de sua função ritual" ${ }^{\prime}$. Pode-se afirmar que a aura é cingida pela autenticidade e pela unicidade e estas qualidades denotam o valor da obra de arte, entretanto, acrescenta Benjamin, justamente "o que se atrofia na era da reprodutibilidade técnica da obra de arte é sua aura"", por essa razão, uma profunda transformação apodera-se das artes visuais a partir da reprodutibilidade técnica e uma verdadeira revolução se faz: "a obra de arte se emancipa, pela primeira vez na história, de sua existência parasitária, destacando-se do ritual"10.

Neste novo registro em que está inserido o objeto artístico produzido através das técnicas de reprodução das imagens e prescindindo dos tradicionais valores para existir - a autenticidade e a unicidade, que representam sua aura -, não faz mais sentido procurar pela autenticidade nas cópias produzidas, então "toda a função social da arte se transforma. Em vez de fundir-se no ritual, ela passa a fundar-se em outra práxis: a política" ${ }^{, 11}$, e isto se dá por efeito da especificidade da técnica de produção da própria obra, quer dizer, o aspecto técnica imanente no cinema, e que também já estava manifesto na fotografia, proporciona, inicialmente, um embate entre as forças naturais e o homem. E não obstante Benjamin afirmar que "uma das funções sociais mais importantes do cinema é criar um equilíbrio entre o homem e o aparelho"12, é principalmente nesta forma de arte impregnada dos "estigmas do capitalismo" "13, como disse Adorno, que num filme - constituído como uma produção coletiva - o propendido é sempre a difusão maciça desta mercadoria cultural, é sempre a abundante comercialização do produto ${ }^{14}$ que interessa aos produtores; este propósito acena para uma profunda mudança entre a "relação da massa e a arte"15. Esta transformação solicitou de Benjamin ponderações sobre percepção e recepção da obra de $\operatorname{arte}^{16}$.

Para o filósofo, o cinema é, a priori, sempre objeto de recepção coletiva e "controlada", pois no cinema "as reações do indivíduo, cuja soma constitui a reação coletiva do público, são condicionadas, desde o início, pelo caráter coletivo desta reação. Ao mesmo tempo em que estas reações se manifestam, elas se

\footnotetext{
${ }^{8}$ BENJAMIN, 1994, p. 171/ Cf. Habermas sobre o caráter ritualístico: "Benjamin não explica essa desritualização da arte; ela deve ser compreendida como parte daquele processo histórico de racionalização que o desenvolvimento das forças produtivas introduz nas formas sociais da vida, com as transformações do modo de produção - também Max Weber usa o termo "desencantamento"” In: HABERMAS, 1980, p. 182.

${ }^{9}$ BENJAMIN, 1994, p. 168.

${ }^{10}$ BENJAMIN, 1994, p. 171.

${ }^{11}$ BENJAMIN, 1994, p. 171-172.

12 BEINJAMIN, 1994, p. 189.

${ }^{13}$ BENJAMIN, 1991, p. 173. [L'œuvre d'art à l'époque de sa reproduction mécanisée (1936): La contribution d'Adorno à la discussion sur le fond (p. 169-176)].

${ }^{14}$ No capítulo "Exigência de ser filmado" do nosso texto-base, Benjamin critica todo o mecanismo fraudulento que rodeia a indústria cinematográfica em detrimento do "interesse original das massas pelo cinema" e afirma: "Vale para o capital cinematográfico o que vale para o fascismo no geral: ele explora secretamente, no interesse de uma minoria de proprietários, a inquebrantável aspiração por novas condições sociais. Já por essa razão a expropriação do capital cinematográfico é uma exigência prioritária do proletariado. In: BENJAMIN, 1994, p. 185.

${ }^{15}$ BENJAMIN, 1994, p. 187.

${ }^{16} \mathrm{E}$, embora não esteja em primeiro plano a questão da nova forma de existência da arte no período moderno, ou seja, o objeto artístico como mercadoria, o tema subjaz em todo o texto benjaminiano. Em outro texto, Benjamin cita um trecho de Brecht sobre esta condição da obra de arte: "desde que a obra de arte se torna mercadoria, essa noção (de obra de arte) já não pode ser mais aplicada; assim sendo, devemos, com prudência e precaução - mas sem receio - renunciar à noção de obra de arte, caso desejemos preservar sua função dentro da própria coisa como tal designada...” In: BENJAMIN, 1993, p. 12, nota 11.
} 
controlam mutuamente" ${ }^{17}$, logo, eis o mote que revela a disparidade receptiva entre a pintura e o cinema, quer dizer, a recepção individual e a coletiva.

Pelo ponto de vista do realizador, o pintor ou o cinegrafista, Benjamin observa que a realidade apresentada num filme, através do cinegrafista, é totalmente adversa daquela dada na tela do pintor. Conseqüentemente, desta relação entre cinegrafista e pintor surge determinado ganho ao cinegrafista, segundo Benjamin, e tal ganho refere-se a uma descrição imagética mais veraz da realidade em comparação ao trabalho do pintor. Isto equivale a dizer que no cinema, a realidade, ainda que composta por inúmeros fragmentos é devassada, penetrada; porém, na tela do pintor, a despeito da imagem ser apresentada em sua totalidade "há uma distância natural entre a realidade dada e ele próprio"18. É na disparidade entre a penetração e a distância que se encontra o nó da recepção tátil benjaminiana, a qual encontra na arquitetura e no cinema os elementos-símbolo da mudança da recepção da arte contemporânea, sobretudo no que tange à recepção da arte pela "massa". Para Benjamin a arquitetura é a arte que guarda uma dupla forma de recepção, pois ela se dá ao receptor pelo uso e pela percepção, logo, pelo tátil e pelo ótico. O mesmo ocorre com o cinema, mas no domínio do efeito de choque que decorre das sequiências de imagens. Pode-se afirmar que a aparelhagem cinematográfica uniu a estática fotografia ao movimento, e o fenômeno da persistência retiniana alterou, consideravelmente, a percepção visual. Deste ponto em diante e, através da sequiência de imagens, movimento, visão e temporalidade tornam-se componentes não apenas do processo perceptivo, mas também do processo cognitivo. O cinema exige mais do sistema sensorial, "chegou o dia em que o filme correspondeu a uma nova e urgente necessidade de estímulos. No filme, a percepção sob a forma de choque se impõe como princípio formal. Aquilo que determina o ritmo da produção na esteira rolante está subjacente ao ritmo da receptividade, no filme"19. O conceito de choque citado está diretamente relacionado à técnica da montagem no cinema, e esta, por sua vez, alude ao modo de recepção distração; na concepção de Benjamin este é um dos dois modos de recepção da obra de arte, o outro é o recolhimento ou a contemplação. A arquitetura e o cinema, então, exigem a distração do receptor estético; já para o apreciador de uma pintura, o recolhimento é o essencial.

Ponderando acerca da noção de distração, afirma Carla Milani Damião, que ela "se revela como um modo de percepção disseminador, deixando à consciência apenas o papel de receptar e assimilar os choques" ${ }^{20}$. Contrária a essa noção, na contemplação ou recolhimento, a fruição da obra remete a abstrações, o espectador é convidado diante da obra "à contemplação; diante dela ele pode abandonar-se às suas

\footnotetext{
${ }^{17}$ BENJAMIN, 1994, p. 188.

${ }^{18}$ BENJAMIN, 1994, p. 187.

19 BENJAMIN, 2000, p. 125/ Cf.: A forma de choque acima citada se refere ao conceito freudiano de "choque traumático". Segundo Carla Milani Damião "o conceito de interrupção (Unterbrechung) está relacionado à ideia de vivência de choque (Schockerlebnis)..." e este "passa a ser um conceito-chave para a identificação das situações características da modernidade, estando diretamente associada à vivência (Erlebnis) como tipo de experiência individual e solitária do homem moderno". In: DAMIÃO, 2007, p. 198. [Sobre o significado de épico na interpretação benjaminiana de Brecht (p. 185-203)].

${ }^{20}$ DAMIÃO, 2007, p. 199.
} 
associações" ${ }^{21}$, diz o Benjamin. A contemplação é sempre individual e interiorizada, e a supracitada “distância natural" do pintor é a mesma "distância sólida" adorniana "que permite o prazer"22 na apreciação de uma obra de arte. Na recepção contemplativa a visão é o sentido-chave, já na distração o elemento tátil opera "através do efeito de choque de suas seqüências de imagens" ${ }^{23}$; destarte, pode-se dizer que a primeira recepção é óptico-contemplativa e a segunda tátil-distraída, sendo que a última é a do receptor do cinema e da arquitetura (com sua dupla forma de recepção). De acordo com o filósofo advêm destas noções dois movimentos: na primeira recepção o espectador pode transformar o objeto observado em "objeto de devoção" (voltando assim à forma tradicional e ritualística do objeto), e na recepção ulterior, a tátildistraída, o espectador do filme conseguiria, por meio da vivência do choque (proveniente da interrupção), uma ruptura com a ilusão através da fragmentação. Desse modo, a tradição estética se mantém no recolhimento e deixa para a vanguarda a distração. Entre o recolhimento e a distração há ainda outra concepção que se considera azada no meio desta reflexão, a diversão, e esta se aplica mais especificamente ao teatro de Bertolt Brecht.

II

Conceitos como choque, interrupção, distração participam igualmente dos textos reflexivos de Bertolt Brecht e de Walter Benjamin. O conceito diversão reporta-se, preferentemente, a Brecht e ao teatro $^{24}$. A noção de diversão aparece no texto-base benjaminiano no sentido do senso comum: "para as massas, a obra de arte seria o objeto de diversão, e para o conhecedor, objeto de devoção"25, entretanto, na conferência de 1934, O autor como produtor, ao discorrer acerca do teatro épico brechtiano, Benjamin afirma que "não há melhor ponto de partida para a reflexão que o riso. As vibrações físicas produzidas pelo riso oferecem melhores ocasiões para o pensamento que as vibrações da alma. O teatro épico só é luxuriante nas ocasiões que oferece para o riso" ${ }^{26}$. O posicionamento do filósofo harmoniza-se com as teorias pedagógico-dramáticas ${ }^{27}$ brechtianas, pois para Brecht, o conceito de diversão deve ser explorado didaticamente, como um "aprender divertindo-se". Este "aprender divertindo-se" está condicionado ao sucesso do "ensinar", logo, a diversão não encontra nas teorias brechtianas um caráter contraproducente, ao

\footnotetext{
${ }^{21}$ BENJAMIN, 1994, p. 192.

${ }^{22}$ ADORNO, 1998, p. 178./ Cf.: Otília Arantes sobre o recolhimento adorniano: "a experiência solitária da obra encerra um impulso emancipatório de evidente conseqüência social. Essa a chave o recolhimento adorniano". In: ARANTES, 1999, p. 163.

${ }^{23}$ BENJAMIN, 1994, p. 194.

${ }^{24} \mathrm{O}$ conceito diversão age simultaneamente como modo de recepção e meio de aprendizado, por isso, torna-se interessante pensar aqui nele como um ponto de cruzamento. Vale salientar que, segundo Carla Milani Damião, os textos brechtianos que se referem à diversão como qualidade pedagógica para aprendizagem no teatro foram escritos em 1936, ou seja, posteriores ao escritos de Benjamin sobre o teatro épico de Brecht, que ressaltavam, principalmente, "a dimensão crítico-reflexiva que surge a partir dos momentos de interrupção". In: DAMIÃO, 2007, p. 201, nota 14.

${ }^{25}$ BENJAMIN, 1994, p. 192.

${ }^{26}$ BENJAMIN, 1994, p. 134. [O autor como produtor (p. 120-136). Conferência pronunciada no Instituto para o Estudo do Fascismo, em 27 de abril de 1934].

${ }^{27}$ Segundo Benjamin, se "o programa pedagógico do marxismo é determinado pela dialética entre o ato de ensinar e o de aprender, algo análogo transparece no teatro épico, no confronto constante entre a ação teatral, mostrada, e o comportamento teatral, que mostra a ação”. In: BENJAMIN, 1994, p. 88 [Que é o teatro épico? Um estudo sobre Brecht (p. 78-90)]
} 
contrário, aliadas à "didática" diversão estão a distância estética e a distração, sendo que esta última ainda inverte o negativo em positivo, e como afirma Otília Arantes, ela ainda "transforma a "distração" em ponto de vista do interessado" 28 .

Tanto para o filósofo como para o homem de teatro a recepção distraída, ou a distração "esclarecida", recorrendo novamente a Otília Arantes, opera latente e profundamente nas estruturas perceptivas, e para Benjamin o cinema é o cenário privilegiado onde a coletividade procurando distração encontra a "dominante tátil, que rege a reestruturação do sistema perceptivo" ${ }^{29}$. No entanto, Benjamin não restringe a percepção apenas à arte cinematográfica ou a arquitetura, mas acredita que também "as formas do teatro épico correspondem às novas formas técnicas, o cinema e o rádio" ${ }^{\text {30 }}$, ou seja, o teatro brechtiano aplicando a técnica do distanciamento estético por meio da interrupção torna-se análogo à técnica de montagem no cinema.

Assim sendo, as artes técnicas que dialogam com o coletivo são as artes mais imbricadas politicamente com este coletivo, e na apreciação de ambos os pensadores é factível que através da recepção distraída um tácito espaço crítico-reflexivo germine, afinal, a recepção distraída se realiza pelo hábito e não pela atenção, e "através da distração, como ela nos é oferecida pela arte, podemos avaliar, indiretamente, até que ponto nossa percepção está apta a responder a novas tarefas [...] a arte conseguirá resolver as mais

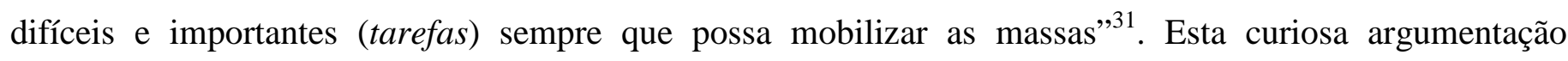
benjaminiana encontra eco na célebre e generosa proposição stendhaliana ${ }^{32}$ que afirma que a obra de arte contém a promessa de felicidade, logo, se tal afirmação pode ser considerada factual, então, não haveria nenhum entrave na realização do argumento benjaminiano, mas será que esta ilação procede?

\section{III}

As últimas décadas do século XX presenciaram uma intensa metamorfose na instituição museu. $\mathrm{O}$ “museum-boom dos anos 80"33 levou um novo público a estes espaços outrora restritos ao connaisseur, ao iniciado na alta cultura; atualmente os museus assemelham-se a uma casa de espetáculos, e não mais ao lugar melancólico onde "achamo-nos sempre um pouco perdidos e desolados... ... sozinhos diante de tanta arte" ${ }^{34}$, como disse Paul Valéry nos idos da década de 1930.

Parte desta mudança deveu-se a grande ebulição surgida nas artes nos anos de 1950 e $1960^{35}$, a qual colocou em xeque o próprio espaço expositivo e a concepção de museologia, ou seja, todo o cabedal que regia o espaço museu passou por alterações várias. A alteração ocorrida nos museus a partir da segunda

\footnotetext{
${ }^{28}$ ARANTES, 1991, p. 163.

${ }^{29}$ BENJAMIN, 1994, p. 194.

${ }^{30}$ BENJAMIN, 1994, p. 83.

${ }^{31}$ BENJAMIN, 1994, p. 194.

${ }^{32}$ BAUDELAIRE, 1976, p. 420, nota 3, p. 1296.

33 ARANTES, 1999, p. 80.

${ }^{34}$ VALÉRY, 2008, p. 33.

35 Infelizmente por questões práticas não poderemos aprofundar a questão da recepção da obra de arte e remontar a Marcel Duchamp ou às críticas de Marinetti aos museus, ou mesmo antes, a Poe ou a Baudelaire; então, sucintamente partiremos do período sugerido para abordar o assunto.
} 
metade do século XX revela ainda que a relação entre a obra de arte visual e o público tornou-se mais complexa, exigente; pode-se dizer, grosso modo, que o olhar do receptor começa a sofrer alterações categóricas a partir de 1950-1960, e, a partir da Pop-Art estadunidense, na qual o artista pop se preocupa, notadamente, com o contex to em que a obra esta inserida, sucede uma integração entre o receptor e o mundo como elementos essenciais do projeto artístico, e como conseqüência, "a obra de arte deixa de ser pensada em termos de estrutura para ser concebida como processo, experiência vital, performance" ${ }^{36}$; os happenings, as performances, e as instalações invadem os museus. Na Pop-Art o objetivo de apreender a realidade pela ausência de subjetividade origina a ambientação e a participação: é a plena supressão da distância entre o receptor e a obra, que somada à perda do mistério aurático, altera, sobremaneira, a recepção e a percepção de uma obra de arte. Copiosamente as novidades se impõem e se estabelecem; atualmente, noções como interatividade, arte e tecnologia, hipermídia, entre outros termos, procuram aplicar e explicar a provocativa tríade: autor-obra-receptor.

Outro dado importante que alterou bastante o "templo das Musas" foi o lasseamento da noção de patrimônio (conjunto de bens). Após juntar-se ao patrimônio a noção de cultura, perfazendo então o conceito de "patrimônio cultural", um horizonte mais amplo pôde ser avistado no tocante a produção humana. Ademais, o trabalho das curadorias, as pesquisas envolvendo a conservação das obras do acervo, e a criação de um espaço físico específico para o armazenamento das peças do museu (a reserva técnica), também colaboraram para transformar de modo definitivo os espaços dedicados à arte. Os museus foram sendo cada vez mais pensados e estruturados como empresas a serviço da cultura, e como empresas assumidas, eles prezam por manter sempre cativos seus clientes. Por isso, é sintomático que muitos museus passem por uma reciclagem arquitetônica, e vez por outra, outros tantos são inaugurados com diversos atrativos, que não apenas o acervo, pois na época atual não basta um museu ter em boas condições as tradicionais salas de exposições, antes, deve manter em sua estrutura ao menos uma loja, um restaurante ou uma cafeteria, um auditório para projeção de filmes, espetáculos musicais, ou palestras, e um setor educativo. Outrossim, o espaço museológico é agora multiaxial e sua existência se torna praticamente insustentável sem o exercício dialético promovido pelo consumo enleado à fruição.

O caso clássico de museu contemporâneo que encetou a reflexão acerca da nova postura dos museus é o Beaubourg (Centre Pompidou), em Paris, inaugurado no final dos anos 1970. Ele é o exemplo do quanto se alteraram os museus em alguns poucos decênios. Para o filósofo Jean Baudrillard, além de o Beaubourg, ou a coisa Beaubourg, como ele o nomeou, possuir uma arquitetura que denuncia nossa célere temporalidade, o centro se estabelece como um "monumento aos jogos de simulação de massa" que absorve "a energia cultural devorando-a" em que aproxima o museu a um "hipermercado da cultura" 38 desvia-o mais e mais de um recinto que

\footnotetext{
${ }^{36}$ GUELFI, 2001, p. 122.

${ }^{37}$ BAUDRILLARD, 1997, p. 156.

${ }^{38}$ BAUDRILLARD, 1997, p. 166.
} 
conserva a alta cultura; para ele o Beaubourg é um espaço de "dissuasão cultural" 39 que possui conteúdos culturais "anacrônicos porque a este invólucro arquitetônico só poderia ter correspondido o vazio interior" 40 . Tais ponderações baudrillardianas reportam à determinada reverência perdida como sanciona a afirmação de Cézanne na virada do século XIX para o século XX, a saber, Cézanne pretendia que seu trabalho fosse ““"sólido e durável como a arte dos museus”, como "a perpetuidade do sangue” em Rubens”41. Logo, é inevitável não detectar um descompasso entre a procura essencial de Cézanne, que tinha no museu de sua época um local dedicado à grande arte, e a efetiva proposta dos museus contemporâneos.

Nestes tempos pós-modernos conceitos hostis entre si, como por exemplo, irreverência e conservadorismo, transgressão e condescendência, convivem comodamente num mesmo espaço expositivo consoante com gosto do curador. O desaparecimento da clássica "museufobia das vanguardas"42 deu-se em sincronia com a nova posição assumida pelo museu, a de "mandachuva da indústria cultural"43, como afirma Andreas Huyssen. Todavia, não foram apenas os museus que se adaptaram às vertigens dos novos tempos, mas a própria arte e o público foram também, paulatinamente, se refazendo.

Quando as grandes cidades ${ }^{44}$ com seus modernos e equipados museus, e seus vultosos patrocínios, vangloriam-se do extraordinário número de visitantes nesta ou naquela exposição, tem-se a inexata impressão de que a "pequena multidão de usuários que acorre os novos museus e parece se divertir com a desenvoltura de futuros especialistas" 45 está, de modo genuíno, desfrutando prazerosamente da grande arte; no entanto, a diversão que emana dos visitantes dos mega-museus com suas mega-exposições não é a similar brechtiana do "aprender divertindo-se". Seguramente é o contrário, pois a diversão que se aplica aos hodiernos museus é ato de puro entretenimento alheio a qualquer tipo de inquietação ou busca pelo belo, ou pela arte. Na perspectiva do visitante dos museus, o recolhimento, a relação mais próxima daqueles que apreciam as obras que ali estão, foi substituído pelo registro da máquina fotográfica, ou da filmadora, que comprova a visita do pseudo-apreciador ao espaço. A promissora distração-tátil de Benjamin que serviria como um paralelo entre a "massa" e a obra de arte feita para ela num viés desiluso é apenas "apreensão superficial e maximamente interessada da obra enquanto bem de consumo" ${ }^{46}$, afirma Otília Arantes.

Deste modo, se os modelos de recepção aventados outrora - distração, contemplação e diversão - não dão conta de explicar a abundante e voraz visitação que está acometendo os museus pelo mundo afora, então se deduz que o atual visitante de um museu não vai até ele, propriamente dito, para apreciar seu acervo ou uma dada exposição em cartaz, mas antes, vai e o freqüenta, sobretudo, ambicionando usufruir de certa atmosfera, de certa aparência de refinamento que só a alta cultura pode oferecer, pois, "a palavra arte vem

\footnotetext{
${ }^{39}$ BAUDRILLARD, 1997, p. 165.

${ }^{40}$ BAUDRILLARD, 1997, p. 159.

${ }^{41}$ Conversations avec Cézanne apud : DELEUZE; GUATTARI, 2007, p. 215.

${ }^{42}$ HUYSSEN, 1999, p. 228.

${ }^{43}$ HUYSSEN, 1999, p. 229.

${ }^{44}$ Cf. Huyssen: "Por um lado, as novas políticas de cultura se aproveitam claramente do museu para melhorar a imagem de uma cidade ou companhia: Berlim e Nova Iorque precisam tanto dessa melhoria de imagem quanto a Mobil ou a Exxon, dois dos maiores patrocinadores de superproduções nos Estados Unidos”. In: HUYSSEN, 1999, p. 233.

${ }^{45}$ ARANTES, 1991, p. 164.

${ }^{46}$ ARANTES, 1991, p. 164.
} 
impregnada de glamour e elevados propósitos [...] arte é também o corporativismo dos marchands e curadores [...] Nos museus, a arte é o consolo da classe média. Em mãos de particulares é o estandarte da fortuna oficializada e a primeira aquisição do novo rico" ${ }^{, 47}$. Acrescenta-se a tal magnetismo o advento das curadorias cenográficas, que colaboraram para alterar ainda mais a relação entre a arte e o receptor estético, e delas, afirma-se sem nenhum juízo de qualidade que, se nesta modalidade expositiva sugere-se um apelo à interatividade, ao deslocamento, à fantasia, e mesmo que tais atributos já participassem das exposições de "formato tradicional", porém, de modo latente, as curadorias cenográficas revelam-se hoje como dispositivos assumidamente teatrais com um fito, o de atrair o maior número de pessoas ao recinto expositivo, pois assim é conceitualizada uma exposição de sucesso. Assim, dentro desta concepção de apreciação da arte, o conjunto de obras que deveria merecer plena atenção do apreciador, age como destaque, ou chamariz, e que, no entanto, permanece quase anônimo no nobre recinto dedicado a ele. A obra de arte, tal como uma eminência parda, parece restrita a legitimar a entrada do visitante apressado ao local, que se tornou ponto turístico, e não mais o espaço de fruição da arte.

Nos modernos museus o visitante deleita-se com a beleza da arquitetura, com os confortos oferecidos com a segurança do local, com a vista única que os mirantes, estrategicamente colocados, proporcionam ${ }^{48}$, e com a aplicação de certas regras de civilidade que denotam o caráter universal do espaço. A forma de sociabilidade desenvolvida entre os museus e os receptores estéticos hodiernos parece, mormente em virtude de seu próprio espaço, sempre protegido e alheio à realidade, e, conseqüentemente, mais próximo da simulação, segundo Baudrillard, pois, simultaneamente, estes espaços buscam com suas lojas, cafés e jardins, a reprodução da própria vida social, gerando, porém, "formas puras de socialização controlada"49. Tendo este horizonte à frente é natural que o recinto anteriormente dedicado à contemplação é agora recinto de distração, e o olhar do apreciador da obra de arte em um museu torna-se cada vez mais tátil, rápido, distraído. Oferecem-se nos espaços consagrados a arte tudo o que um moderno shopping center oferece: conforto, beleza, comodidade, e, sobretudo, bens de consumo, tais como catálogos, livros, objetos de decoração e uso pessoal, enfim, todo tipo de souvenir que atesta a visita ao museu ${ }^{50}$.

No tocante aos suvenires é clara a intenção dos museus em participar, por meio de suas lojas, ativamente do comércio. A vasta gama de produtos oferecidos vem todos com a chancela de "feito especialmente para", e muitas usam como referência as imagens das obras mais destacadas do próprio acervo do museu; são canecas e copos, relógios e semi-jóias, lenços e quinquilharias, agendas e lápis de todos os tipos, objetos lúdicos como bonecas e jogos, enfim, lembrançinhas para todos, adultos e crianças, arrogados como produtos. Entretanto, não é só isso, pois as lojas de museus, ou as "lojas de design", como se autonomeia a loja do MoMA, estão cada vez mais se assumindo como comércio autônomo em busca de

\footnotetext{
${ }^{47}$ ARANTES, 1999, p. 85.

${ }^{48}$ ARANTES, 1991, p. 169.

${ }^{49}$ BAUDRILLARD, 1991, p. 166.

${ }^{50}$ Neste ponto poder-se-ia pensar na relação entre os museus e as grandes bibliotecas públicas e nacionais, principalmente no tocante aos cânones técnicos e a interação espacial. Todavia, tal exame merece uma reflexão aprofundada, pois é na figura do receptor que ocorre uma grande adversidade.
} 
seu próprio mercado, e ao invés de usar as referências imagéticas do acervo em seus produtos, estão criando novas mercadorias, ou requentando antigas, com a ajuda de um variegado exército de designers e artistas contemporâneos. Logo, o anteriormente prosaico e apressado visitante dos museus, já não precisa ir a um museu para "respirar" arte, basta consumi-la numa das lojas (avulsas) do grande museu espalhadas pelo mundo. E mesmo se atualmente ainda são em pequeno número as lojas-filiais dos grandes museus, tal fenômeno sugere-se como uma forte tendência expansionista para um futuro próximo. E da mesma maneira que o visitante sente-se civilizado na lojinha do "templo das Musas", sentir-se-á ele ainda mais atualizado e conectado com o mundo moderno numa loja autônoma do museu que traz sempre novos objetos, pois tudo o que se oferece ali, ou é parte da tradição cultural (estampada numa caneca), ou é uma mercadoria de designer que se sugere como parte da futura história cultural. Nos espaços do museu e da loja o visitante sente-se incluído numa sociedade polida e agradável que produziu uma segura e estatizada estrutura para fomentar ${ }^{51} \ldots$ o consumo.

\section{IV}

E após tal constatação, finalizemos nossas ponderações: a impressão mais forte que insiste em permanecer é a concernente ao caminho sem volta dos museus; parece que doravante estes espaços preocupar-se-ão cada vez mais em manter sua posição de vanguarda, não das artes, mas do consumo. Tudo concorre para que eles se estabeleçam como os grandes astros urbanos, pois melhor que os shopping centers, os museus preservam algo único para a humanidade, a saber, sua própria memória, "porque afinal sempre é bom ter tradição" ${ }^{, 2}$, e a possibilidade de associar-se a um espaço que agrega valores de tão alta monta atrai tanto visitantes, afoitos em sua maioria, quanto patronos e seus pares. O espaço está cada vez mais restrito ao receptor estético contemplativo, pois a pletora que acomete os museus, que vai de turistas a grupos de estudantes, não colabora com o receptor que visa ao exame minucioso da obra. No singular mundo em que vivemos, em "uma sociedade em que finalmente tudo está à venda" ${ }^{33}$, a instituição museu reverteu, e pelo que se mostra de modo definitivo, a rebelde museufobia pela profícua museufilia.

\footnotetext{
${ }^{51}$ A fruição do museu (fala-se aqui do recinto que acolhe obras de arte em seu significado tradicional) pelo visitante é, muitas vezes, uma obrigação, senão um fardo, e está distante do prazer que ele poderia obter, talvez, num destes recentes museus temáticos, como por exemplo, o Museu da Língua Portuguesa, ou o Museu do Futebol (ambos em São Paulo), ou o Musée de la Publicité (em Paris), que apesar de carregar o mesmo nome, "museu", naturalmente, não contam com o mesmo peso simbólico.

${ }^{52}$ ADORNO, 1998, p. 174.

${ }^{53}$ Paulo Arantes citando um colaborador da revista norte-americana New Criterium. In: ARANTES, 1999, p. 99.
} 
Referências

ADORNO, Theodor W. Prismas. Crítica cultural e sociedade. Trad. Augustin Wernet; Jorge de Almeida. São Paulo: Ática, 1998.

ARANTES, Otília Beatriz Fiori. Os Novos Museus (p. 161-169). In: Novos Estudos CEBRAP, $n^{\circ} 31$, São Paulo, outubro de 1991.

ARANTES, Paulo Eduardo. A sofística da assimilação (ps. 75-100). In: Praga - Revista de Estudos Marxistas, Vol. 8, São Paulo, 1999.

BAUDELAIRE, Charles. Euvre complètes II. Paris: Gallimard/ Bibliothèque de la Pléiade, 1976.

BAUDRILLARD, Jean. A arte da desaparição. Trad. Anamaria Skinner. Rio de Janeiro: Editora UFRJ, 1997.

Simulacros e simulação. Trad. M. J. da C. Pereira. Lisboa: Relógio d'água, 1991.

BENJAMIN, Walter. Magia e técnica, arte e política: ensaios sobre literatura e história da cultura. Trad. Sérgio Paulo Rouanet. São Paulo: Brasiliense, 1994.

. Charles Baudelaire um lírico no auge do capitalismo. Trad. José Carlos Martins Barbosa; Hemerson Alves Baptista. São Paulo: Brasiliense, 2000.

Textos Escolhidos. Coleção: Os Pensadores. Trad. José Lino Grunnewald, et alii. São

Paulo: Abril, 1993.

Écrits français. Paris: Gallimard, 1991.

DAMIÃO, Carla Milani. Sobre o significado de épico na interpretação benjaminiana de Brecht (p. 175-85). In: Leituras de Walter Benjamin/ Márcio Seligmann-Silva (Org.). São Paulo: Fapesp/ Annablume, 2007.

DELEUZE, Gilles; GUATTARI, Félix. O que é a filosofia? Trad. Bento Prado Jr.; Alberto Alonso Muñoz. São Paulo: Editora 34, 2007.

GUELFI, M. L. F. O tempo do clichê e a estética do olhar na ficção contemporânea (p. 119-31). In: Ipotesi - Revista de Estudos Literários. Juiz de Fora, v. 5, n.1, 2001.

HUYSSEN, Andreas. Memórias do Modernismo. Trad. P. Farias. Rio de Janeiro: Editora UFRJ, 1999.

VALÉRY, Paul. O problema dos museus. Trad. Sônia Salzstein. In: Revista Ars. São Paulo: ECA/ USP, Ano 6, n⿳⺈ 12, 2008. 